University of Nebraska - Lincoln

DigitalCommons@University of Nebraska - Lincoln

2012

\title{
The General Ensemble Biogeochemical Modeling System (GEMS) and its Applications to Agricultural Systems in the United States
}

Shuguang Liu

Zhengxi Tan

Mingshi Chen

Jinxun Liu

Anne Wein

See next page for additional authors

Follow this and additional works at: https://digitalcommons.unl.edu/natrespapers

Part of the Natural Resources and Conservation Commons, Natural Resources Management and Policy Commons, and the Other Environmental Sciences Commons

This Article is brought to you for free and open access by the Natural Resources, School of at DigitalCommons@University of Nebraska - Lincoln. It has been accepted for inclusion in Papers in Natural Resources by an authorized administrator of DigitalCommons@University of Nebraska - Lincoln. 


\section{Authors}

Shuguang Liu, Zhengxi Tan, Mingshi Chen, Jinxun Liu, Anne Wein, Zhengpeng Li, Shengli Huang, Jennifer Oeding, Claudia Young, Shashi Verma, Andrew Suyker, Stephen Faulkner, and Gregory W. McCarty 
In: Mark A. Liebig, Alan J. Franzluebbers, \& Ronald F. Follett, eds.

\section{The General Ensemble}

\section{Biogeochemical Modeling}

System (GEMS) and its

Applications to

Agricultural Systems

in the United States

Shuguang Liu ${ }^{1}$, Zhengxi Tan ${ }^{2}$, Mingshi Chen ${ }^{2}$, Jinxun Liü ${ }^{3}$, Anne Wein ${ }^{4}$, Zhengpeng $\mathrm{Li}^{2}$, Shengli Huang ${ }^{2}$, Jennifer Oeding ${ }^{3}$, Claudia Young ${ }^{5}$, Shashi B. Verma ${ }^{6}$, Andrew E. Suyker ${ }^{6}$, Stephen Faulkner ${ }^{7}$, Gregory W. McCarty ${ }^{8}$

${ }^{1}$ U.S. Geological Survey (USGS) Earth Resources Observation and Science (EROS) Center,

Sioux Falls, SD

${ }^{2}$ ASRC Research and Technology Solutions, Contractor to USGS EROS Center,

Sioux Falls, SD

${ }^{3}$ Stinger Ghaffarian Technologies (SGT) Inc., Contractor to the USGS EROS Center,

Sioux Falls, SD

${ }^{4}$ U.S. Geological Survey, Menlo Park, CA

${ }^{5}$ Earth Resources Technology (ERT), Inc., Contractor to the USGS EROS Center,

Sioux Falls, SD

${ }^{6}$ School of Natural Resources, University of Nebraska-Lincoln, Lincoln, NE

${ }^{7}$ Aquatic Ecology Laboratory, USGS Leetown Science Center, Kearneysville, WV

${ }^{8}$ U.S. Department of Agriculture (USDA) - Agricultural Research Station (ARS)

Hydrology and Remote Sensing Laboratory, Beltsville, MD

\section{CHAPTER OUTLINE}

General Ensemble Biogeochemical

Modeling System (GEMS) $\mathbf{3 1 0}$

Multiple Underlying Biogeochemical

Models 310

Monte Carlo Simulations 311

Model Inputs: Management Practices and

Others 311

Model Outputs 311

Data Assimilation 311
Simulation of Agricultural Practices: EDCM

as an Example 312

Net Primary Production (NPP) and Improvements in Crop Genetics and

Agronomics 312

Soil Carbon Dynamics 312

Impacts of Soil Erosion and

Deposition 313

$\mathrm{CH}_{4}$ and $\mathrm{N}_{2} \mathrm{O}$ Fluxes 313 


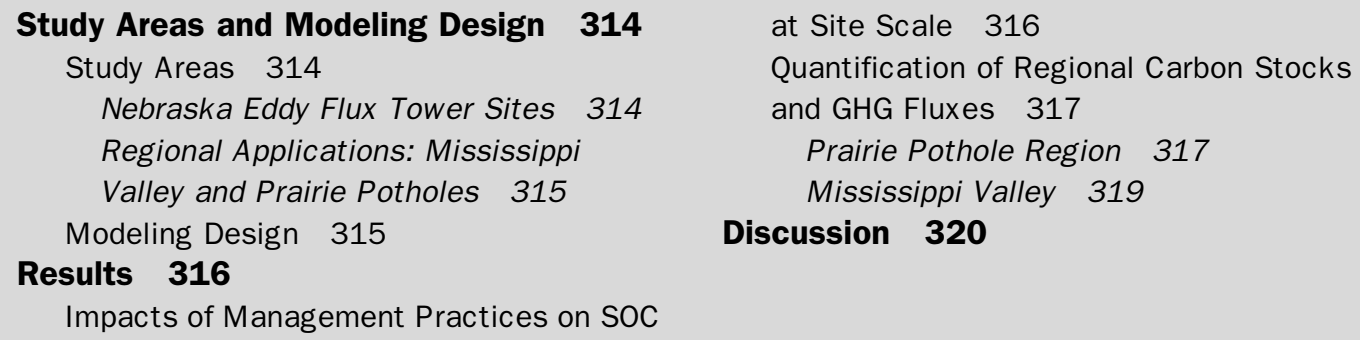

Abbreviations: GEMS, the General Ensemble Biogeochemical Modeling System; EDCM, Erosion-Deposition-Carbon-Model; GHG, greenhouse gas; IPCC, Intergovernmental Panel on Climate Change (IPCC); NPP, net primary production; SOC, soil organic carbon; SSURGO, Soil Survey Geographic Database; NRCS, Natural Resources Conservation Service; NRI, National Resources Inventory; CTIC, Conservation Technology Information Center

\section{GENERAL ENSEMBLE BIOGEOCHEMICAL MODELING SYSTEM (GEMS)}

The General Ensemble Biogeochemical Modeling System (GEMS) (Liu, 2009; Liu et al., 2004c) was developed to integrate well-established ecosystem biogeochemical models with various spatial databases for the simulations of biogeochemical cycles over large areas. Figure 18.1 shows the overall structure of the GEMS. Some of the key components are described below.

\section{Multiple Underlying Biogeochemical Models}

To avoid biases from individual models and to quantify the uncertainty of model outputs, GEMS simultaneously uses multiple site-scale biogeochemical models to simulate ecosystem dynamics over time and space. Previous applications of GEMS (Liu, 2009; Liu et al., 2004a, b, c, 2008; Tan et al., 2005, 2010, 2009b; Zhao et al., 2009) included the application of the CENTURY (Parton et al., 1994, 1987) and Erosion-Deposition-Carbon-Model (EDCM; see Liu et al., 2003). We are in the process of incorporating more models into GEMS including a spreadsheet model to account for carbon storage and greenhouse gas (GHG) emissions using the
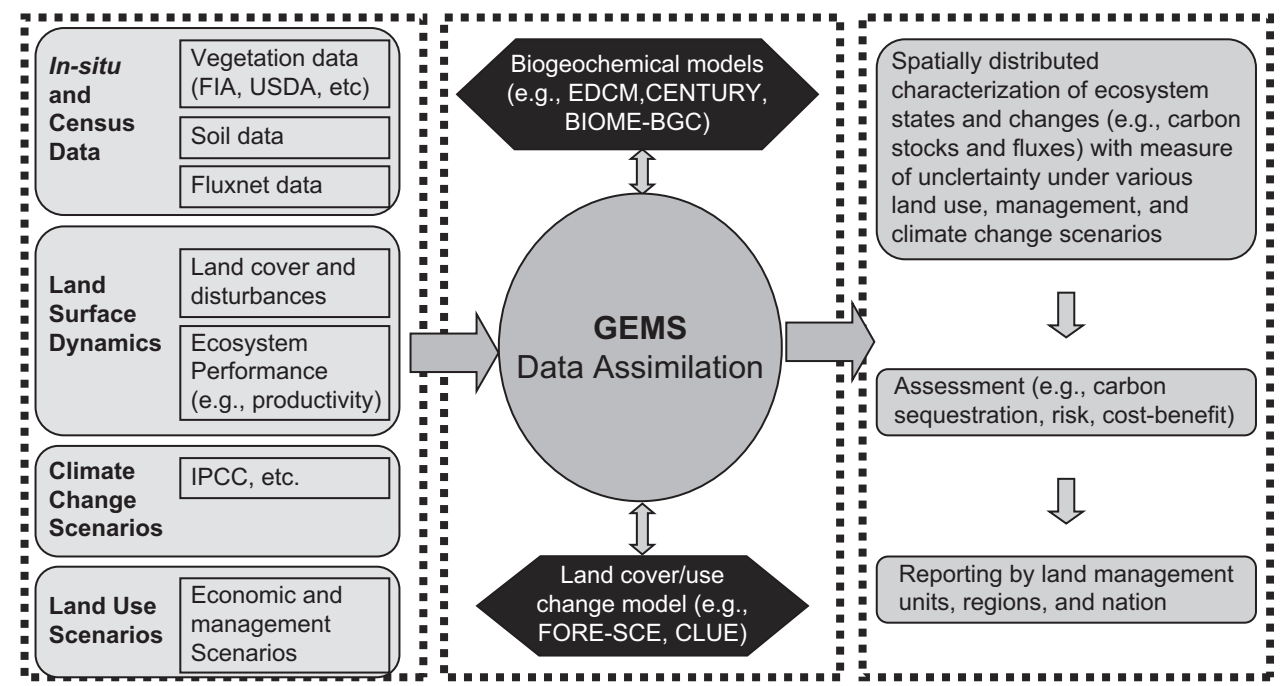

FIGURE 18.1

Structure and major components of the General Ensemble Modeling System (GEMS) 
Intergovernmental Panel on Climate Change (IPCC) approach (IPCC, 2003), wetland biogeochemical models, and other models such as DeNitrification-DeComposition model (DNDC) (Li, 2000).

\section{Monte Carlo Simulations}

In addition to addressing model structure uncertainties using model ensemble, algorithms are implemented in GEMS to address the transfer and impacts of input data uncertainty (Liu, 2009). Monte Carlo ensemble simulations of each simulation unit (one site/pixel or group of sites/pixels with similar biophysical conditions) are used to incorporate the uncertainties and variability (as measured by variances and covariance) of state and driving input variables. Consequently, GEMS can provide uncertainty estimates of the predicted variables in time and space.

\section{Model Inputs: Management Practices and Others}

GEMS is designed to upscale carbon stocks and fluxes from sites to regions with a spatially explicit, dynamic consideration for land cover and land use change. Major driving variables include land cover and land use, climate, soils, disturbances, and management history. GEMS has the capability of modeling the impacts of land-surface disturbances and management practices; these include land use and land cover change, fertilization, cultivation, fallow, crop composition, crop rotation, manure addition, tillage practices, grazing, harvesting options (or residue management), wildfire incidents, and hurricane events (Liu et al., 2008, 2004a, b, c; Tan et al., 2005, 2009a, 2010; Zhao et al., 2009).

In general, channeling all management practices into biogeochemical modeling systems over large areas is a critical challenge because of the complexity, diversity, and spatial and temporal changes of management practices. In addition, most of the management practices cannot be detected using remote sensing techniques; the only data available are agricultural census data at the county, state, or resource management level (including NRI data). Stochastic approaches have been implemented in GEMS to downscale census data to site/pixel level. For example, if all crops are mapped into one category (i.e. cropland) as is often seen in land cover maps, GEMS would use county-level crop composition data (fractions or probabilities of all crops in a county) from an agricultural census to downscale the aggregated class cropland into different crops. In addition, if the land cover maps are snapshots with a time interval longer than one year, GEMS would create the missing annual land cover maps using crop rotation probabilities, which can be obtained from agricultural census data or expert knowledge. Additional examples can be found in Liu (2009).

\section{Model Outputs}

While different biogeochemical models in GEMS have different output variables, their common output variables include gross and net primary productivity, autotrophic and heterotrophic respiration, grain production, dynamics of carbon pools of vegetation and soils, and methane $\left(\mathrm{CH}_{4}\right)$ and nitrous oxide $\left(\mathrm{N}_{2} \mathrm{O}\right)$ fluxes for agricultural systems. At the regional scale, outputs are in standardized file formats (e.g. network Common Data Form (NetCDF)) to facilitate sharing, analysis, and visualization.

\section{Data Assimilation}

Several data assimilation approaches were applied with GEMS for two purposes: (1) to understand and quantify the dynamics of model parameters, and (2) to detect model structure deficiencies (Chen et al., 2008; Liu et al., 2008; Zhao et al., 2010). This capability becomes useful when various observations are applied to calibrate the models at the site to regional scales. 


\section{Simulation of Agricultural Practices: EDCM as an Example}

GEMS can drive a number of biogeochemical models to simulate carbon dynamics and GHG emissions. It is beyond the scope of this chapter to discuss all the algorithms behind individual models in GEMS because model formulations and algorithms are model specific and diverse. Instead in this section, we concentrate on the description of the EDCM, the core, and the first model that was coupled with GEMS.

\section{NET PRIMARY PRODUCTION (NPP) AND IMPROVEMENTS IN CROP GENETICS AND AGRONOMICS}

Representing the net amount of carbon fixed through photosynthesis into an ecosystem, NPP directly regulates the storage and rates of change of organic carbon in vegetation and soil. The prediction of the spatial and temporal change of NPP is critical for the simulation of carbon dynamics for a site or region.

The algorithms for NPP calculation follow the procedures that are well documented in the literature (Metherell et al., 1993; Parton et al., 1993). Calculation algorithms for NPP use the concept of potential primary productivity (PPP) and the limiting effects of moisture, temperature, and nutrients (Liu et al., 2003). Accordingly, PPP is the optimal primary productivity a system can reach without limitation from controlling variables; this is because the limiting factors change over time, as does NPP.

Grain yield and harvest index have increased dramatically since the 1940s at different rates in the U.S. for almost every crop (Hay, 1995), indicating that NPP of these crops must have changed as well. To account for these changes, in addition to using the land use and land cover change data (specifically crop rotation or transition), EDCM incorporates temporal changes in grain yield and the harvest index of crops in simulations. These temporal change patterns were derived from long-term U.S. agricultural census data, thereby allowing for improvements of crop genetics and management practices to be represented in the model. Details of the accounting formula and procedures can be found in Liu et al. (2003).

\section{SOIL CARBON DYNAMICS}

EDCM uses up to 10 soil layers to simulate the dynamics of soil organic carbon (SOC) in the profile. The thickness of the surface soil layer is fixed at the plowing depth at 20 or $30 \mathrm{~cm}$, while the thicknesses of other layers are flexible. Five SOC pools (i.e. metabolic, structural, fast, slow, and passive) in each soil layer are used in EDCM to characterize the quantity and quality of SOC, which follows the practice used by the CENTURY model for the surface soil depth (Metherell et al., 1993; Parton et al., 1987, 1993). The SOC dynamics in each of the layers were simulated as a result of the interactions of the following processes: erosion or deposition, litter input, decomposition, and leaching.

\section{Litter Input: Harvesting and Residue Management}

Plant residue input directly regulates net carbon flux into the soil and, therefore, the amount of SOC storage. The amount of plant residue input varies over time and space, depending on a variety of factors including NPP and harvesting practices. Higher NPP usually means higher residue return to the soil for a given harvesting practice. In practice, the fraction of non-grain biomass removed from the site has important implications to the maintenance of SOC and site fertility. EDCM explicitly tracks the amount of biomass removed from the site as grain and straw, and the amount returned to the soil using NPP, harvest index, and the allocation of biomass in the crop (e.g. grain, aboveground, and belowground) (Liu et al., 2003).

In addition to litter input from the soil surface, soil receives litter input from root mortality in the soil profile. EDCM uses species-specific rooting characteristics (e.g. rooting depth and root vertical distribution) to track the growth and death of roots in each soil layer. 
Finally, the decomposition of plant residues is simulated following the CENTURY 4.0 model according to residue quality indexes (e.g. $\mathrm{C} / \mathrm{N}$ ratio and lignin content) and environmental conditions of the soil (Metherell et al., 1993; Parton et al., 1993).

\section{Soil Carbon Decomposition in Soil Profile}

EDCM simulates the decomposition of SOC in each SOC pool in each layer, calculated by using a pool-specific maximum decomposition rate, layer-specific soil moisture, soil temperature, and soil aeration. The approach is consistent with the CENTURY 4.0 model (Metherell et al., 1993; Parton et al., 1993; Paustian et al., 2012). The effects of soil texture on SOC turnover and lignin content of structural material on SOC decomposition are also considered.

For the simulation of plant growth and SOC decomposition, it is necessary to predict the temporal change of soil moisture in the soil profile. EDCM uses an innovative statistically based approach to simulate the dynamics of soil moisture using monthly precipitation observations, and has been tested successfully in dramatically different climate regions (Li, 2000; Liu et al., 2003).

Soil aeration has a strong impact on SOC decomposition (Li, 2000; Renault and Sierra, 1994; Renault and Stengel, 1994). Several studies (Bouwman, 1989; Van Dam et al., 1997; Voroney et al., 1981) indicate SOC decomposition in subsurface soil horizons is slower than can be explained by soil moisture, temperature, and soil texture, which are usually sufficient for the prediction of SOC dynamics in the surface layer. To our knowledge, no effective physically based modeling approach for the dynamics of soil aeration has been proposed. In EDCM, we hypothesize that soil aeration decreases with soil depth and we model its effect on decomposition using an aeration factor analogous to other factors included in the CENTURY model's treatment of decomposition (Liu et al., 2003, 2010). This approach is based on the assumption that the diffusion of oxygen to deep layers becomes increasingly difficult as depth increases.

Surface and internal drainage has been recognized as a major force driving SOC dynamics in cropland (Baker et al., 2007). In general, poorly drained environments favor SOC accumulation and well-drained environments enhance the soil organic matter decomposition and C emissions (Tan et al., 2004). Improvement in the drainage conditions through an internal tile drainage system within poorly drained soils (such as hydric soils, organic soils, and peatland) can promote crop root development and increase crop biomass (both above and below ground) and grain yields (Kanwar et al., 1988). Since the 1970s, a massive tile drainage system was developed in the Corn Belt (e.g. Iowa, Illinois, Ohio, etc.) to convert native prairies and other hydric soils to highly productive croplands. In order to evaluate the effect of tile drainage on SOC budgets, Liu et al. (2010) added an empirical equation to the EDCM to define drainage conditions at any depth in a soil profile in a tile-drained system.

\section{IMPACTS OF SOIL EROSION AND DEPOSITION}

Erosion and deposition of soil, carbon, and nutrients are important processes affecting carbon balance and GHG emissions (Harden et al., 1999; Liu et al., 2003; McCarty and Ritchie, 2002; Stallard, 1998; Van Oost et al., 2007). A suite of management practices and disturbances impacts soil erosion and deposition. EDCM treats the impacts of soil erosion and deposition on ecosystem productivity, SOC, and GHG fluxes in detail (Liu et al., 2003). It models the evolution of the soil profile as it is altered by soil erosion and deposition processes. Soil properties (e.g. soil texture and bulk density) and processes (e.g. moisture, temperature, and SOC decomposition) are explicitly tracked or simulated in each layer.

\section{$\mathrm{CH}_{4}$ AND $\mathrm{N}_{2} \mathrm{O}$ FLUXES}

In EDCM, $\mathrm{CH}_{4}$ oxidation from agricultural systems is simulated according to the algorithms presented in Del Grosso et al. (2012). Nitrous oxide emissions are simulated as a function of fertilization rate, methods of fertilization, and $\mathrm{N}$ mineralization rate in the soil (Liu et al., 
1999). The model uses the algorithm based on previous work by Cao et al. (1996) and Zhang et al. (2002) and modified to fit in EDCM's monthly step prediction. In wetland systems and rice fields, flooding time and water depth are required inputs to calculate the $\mathrm{CH}_{4}$ emission. Methane production is calculated as the function of temperature and carbon substrate in the flooded soil.

\section{STUDY AREAS AND MODELING DESIGN Study Areas \\ NEBRASKA EDDY FLUX TOWER SITES}

Three flux tower sites were used to calibrate and test the model at the plot scale through data assimilation. The study sites are located at the University of Nebraska Agricultural Research and Development Center near Mead, NE (Figure 18.2). One site (\#1: $41^{\circ} 09^{\prime} 54.2^{\prime \prime} \mathrm{N}$, $96^{\circ} 28^{\prime} 35.9^{\prime \prime} \mathrm{W}, 361 \mathrm{~m}$ ) is equipped with center pivot irrigation and was planted as continuous corn (Zea mays L.). The second site (\#2: $\left.41^{\circ} 09^{\prime} 53.5^{\prime \prime} \mathrm{N}, 96^{\circ} 28^{\prime} 2.3^{\prime \prime} \mathrm{W}, 362 \mathrm{~m}\right)$ is also equipped with center pivot irrigation and was planted to a corn-soybean (Glycine max. L.) rotation. The third site (\#3: $41^{\circ} 10^{\prime} 46.8^{\prime \prime} \mathrm{N}, 96^{\circ} 26^{\prime} 22.7^{\prime \prime} \mathrm{W}, 362 \mathrm{~m}$ ) relies on rainfall and is planted in corn-soybean rotation. Soil at the sites are deep silty clay loams, typical of eastern Nebraska, consisting of four soil series: Yutan (fine-silty, mixed, superactive, mesic Mollic Hapludalfs),

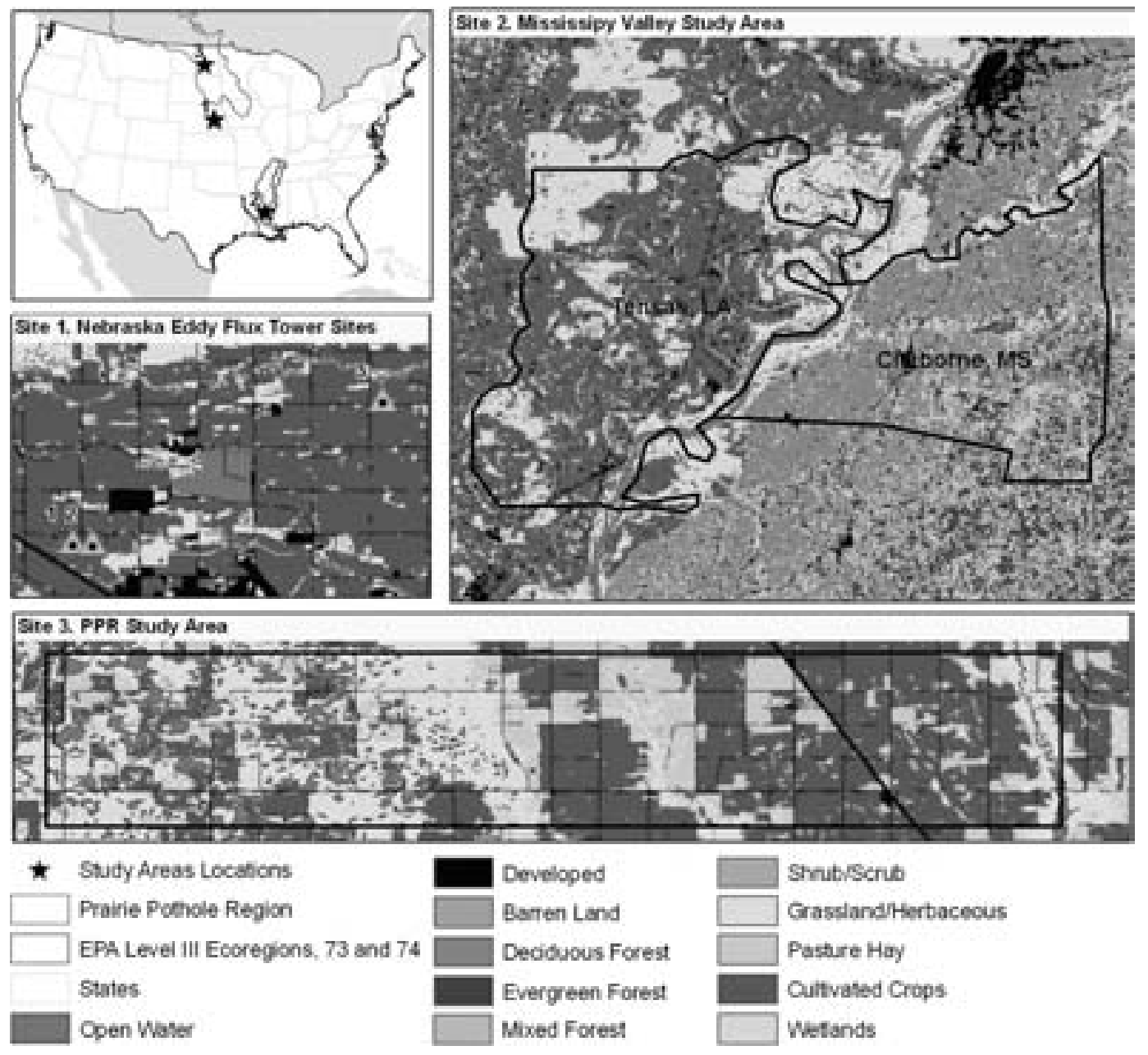

FIGURE 18.2

Study area locations. Please see color plate section at the back of the book. 
Tomek (fine, smectitic, mesic Pachic Argialbolls), Filbert (fine, smectitic, mesic Vertic Argialbolls), and Filmore (fine, smectitic, mesic Vertic Argialbolls).

Prior to initiation of the study, these study sites had a variable cropping history. All three sites were uniformly tilled by disking prior to initiation of the study in 2001 to homogenize the top $0.1 \mathrm{~m}$ of soil and incorporate fertilizers as well as previously accumulated surface residues. The sites have been in no-till since 2001 (except Site 1, where conservation plow was used in the autumn of 2005). Results from the first 4 years documented declining yields with continuous irrigated maize (Site 1) because of difficulties in achieving uniform and adequate plant population due to a heavy litter layer. To address these constraints conservation-plow operations were employed at Site 1, resulting in partial inversion of topsoil layers.

Fluxes of $\mathrm{CO}_{2}$, water vapor, and sensible heat were measured employing eddy covariance systems at all three sites. Details of measurements and analyses of these fluxes and supporting variables are provided in Verma et al. (2005).

\section{REGIONAL APPLICATIONS: MISSISSIPPI VALLEY AND PRAIRIE POTHOLES}

Three counties were selected as representative of the land cover change characteristics in the three regions. Tensas Parish, LA, is located in the Mississippi Alluvial Plain (MAP, EPA Level III Ecoregion 73), a roughly 14 million ha lowland valley shaped by the Mississippi River that extends from southern Illinois to the Gulf of Mexico. The meander belts, valley trains, and back swamps are comprised of fine-textured and poorly drained clay and silt soils (EPA-Western Ecology Division, 2010). Originally, the MAP was dominated by bottomland hardwood forests, but flood control levees have reduced the natural historic floodplain to $10 \%$ of its original extent (Mac et al., 1998). This facilitated the large-scale conversion of the original forest to agricultural cropland, which now covers nearly 59\% of the MAP (Faulkner et al., 2011). In 2001, Tensas Parish land cover was primarily cropland (54\%) followed by wetlands (33\%), forests (3\%), and other (water, developed, etc., 10\%) (Zhu et al., 2010). Nearly twothirds of the MAP is dominated by Sharkey or Tensas clay soils, with the remaining soils consisting of silt loams or silty clay loams (USDA-NRCS, 2006).

Claiborne County, MS, is located in the Mississippi Valley Loess Plain (MVLP, EPA Level Three Ecoregion 74). The MVLP lies adjacent to the eastern edge of the MAP, extending from western Kentucky to Louisiana. It consists of bluff hills, loess plains, and southern rolling plains with loess (wind-blown silt) soils. Vegetation is primarily upland forests dominated by oak (Quercus), hickory (Carya), and southern yellow pine (Pinus) (EPA-Western Ecology Division, 2010). As of 2001, Claiborne County was dominated by forests (73\%, consisting of $47 \%$ deciduous, $6 \%$ evergreen, $9 \%$ mixed, and $11 \%$ anthropogenic disturbances), followed by wetlands $(10 \%)$ and croplands (10\%, includes hay and pasture), and other land cover classes (7\%) (Zhu et al., 2010). All soils in the county are classified as silt loam (USDA-SCS, 1963).

A $256 \mathrm{~km}^{2}$ block in Stutsman County, North Dakota, was selected as an area for GEMS applications in the Prairie Pothole Region of the United States (Figure 18.2). The study area is characterized by a dynamic continental climate with a mean annual precipitation of approximately $440 \mathrm{~mm}$ (Carroll et al., 2005). Native vegetation within the study area was mixed grass prairie. However, the landscape has been substantially altered, and the majority of the prairie grasslands have been converted to agricultural croplands.

\section{Modeling Design}

In this study, GEMS was applied at two spatial scales to illustrate its capability in simulating the consequences of various management practices on soil carbon dynamics and GHG emissions. As an example, GEMS was used to model the impacts of crop rotation, fertilization, crop residue management, irrigation, and tillage at the site scale (i.e. the Nebraska flux tower corn-soybean rotation site). Table 18.1 lists the scenario setups for these simulations. GEMS 


\begin{tabular}{|c|c|c|c|c|c|}
\hline $\begin{array}{l}\text { Case } \\
\text { (see Figure 18.3) }\end{array}$ & $\begin{array}{c}\text { Crop rotation } \\
\text { (yearly) }\end{array}$ & $\begin{array}{l}\text { Cultivation } \\
\text { types }\end{array}$ & $\begin{array}{l}\text { Harvest } \\
\text { types }\end{array}$ & $\begin{array}{l}\text { Fertilization } \\
\left(\mathrm{g} \mathrm{N} / \mathrm{m}^{2}\right)\end{array}$ & $\begin{array}{l}\text { Irrigation } \\
\text { (cm) }\end{array}$ \\
\hline Base & Corn-soybean & CONV-CONV & $G-G$ & $26-5$ & $34-34$ \\
\hline Corn-corn & Corn-corn & CONV-CONV & $\mathrm{G}-\mathrm{G}$ & $26-5$ & $34-34$ \\
\hline Tillage & Corn-soybean & NT-NT & $G-G$ & $26-5$ & $34-34$ \\
\hline Residue & Corn-soybean & CONV-CONV & RED-RED & $26-5$ & $34-34$ \\
\hline Fertilization & Corn-soybean & CONV-CONV & $G-G$ & $15-0$ & $34-34$ \\
\hline Irrigation & Corn-soybean & CONV-CONV & $G-G$ & $26-5$ & $0-0$ \\
\hline
\end{tabular}

Note: CONV: conventional tillage. NT: no tillage.

G: $100 \%$ grain harvested, and other plant materials are left on site.

RED: $100 \%$ grain harvested, $50 \%$ aboveground non-grain biomass removed, and roots not removed.

was calibrated using the eddy flux measurements of carbon exchanges between the cropland and the atmosphere, grain production, and other measurements before being applied to simulate the carbon dynamics and GHG fluxes under various scenarios listed in Table 18.1. In order to address the long-term impacts of management practices, our simulations ran from 2000 to 2050.

To illustrate the applicability of GEMS in incorporating high-resolution remotely sensed land cover and land use change information at the regional scale, we applied the model at the selected area in the Prairie Pothole region from 1972 to 2008. A land cover change database from 2000 to 2008 was created based on the USDA Crop Data Layer derived from the Indian Advanced Wide Field Sensor (AWiFS), which has a spatial resolution of $56 \mathrm{~m}$ (USDA-National Agricultural Statistics Service, 2011). It was assumed that there was no land cover change before 2000 because of lack of information.

In addition to illustrating the wide range of geographic areas suitable for GEMS application, we also applied the model to the Mississippi Valley to simulate the potential of carbon sequestration and reduction of GHG emissions under future climate change and land use scenarios. Annual land cover change scenarios ( $\mathrm{R}$ : "reference land use, land cover, and land management"; L: "enhanced land use and land cover with reference land management") from 2001 to 2050 were predicted using the Forecasting Scenario (FORE-SCE) model (Sohl et al., 2007); those results are presented in Zhu et al. (2010). Monthly climate data were from IPCC SRES (Special Report on Emissions Scenarios) A2 scenario, which is at the higher end of the SRES emissions scenarios characterized by high regional heterogeneity.

For both regional applications, soil information was from the national Soil Survey Geographic (SSURGO) Database. Model simulations were constrained by grain yields for crops from the USDA agricultural census data (USDA-National Agricultural Statistics Service, 2010) and forest growth curves from the USDA Forest Service Forest Inventory and Analysis (FIA) (USDA-Forest Service, 2010).

\section{RESULTS}

\section{Impacts of Management Practices on SOC at Site Scale}

Figure 18.3 shows the impacts of various management practices on SOC dynamics at the corn-soybean rotation site in Nebraska. Apparently, all management activities affected SOC dynamics but the impacts differed. Crop residue management was the most effective practice affecting SOC dynamics directly. A 50\% removal of the residue from the field would reduce SOC by about $840 \mathrm{~g} \mathrm{C} \mathrm{m}^{-2}$ (or 17.3\%) in the 50-year simulation. Figure 18.3 shows that this decrease will continue after 2050. Of course, the magnitude of the decrease depends on the 


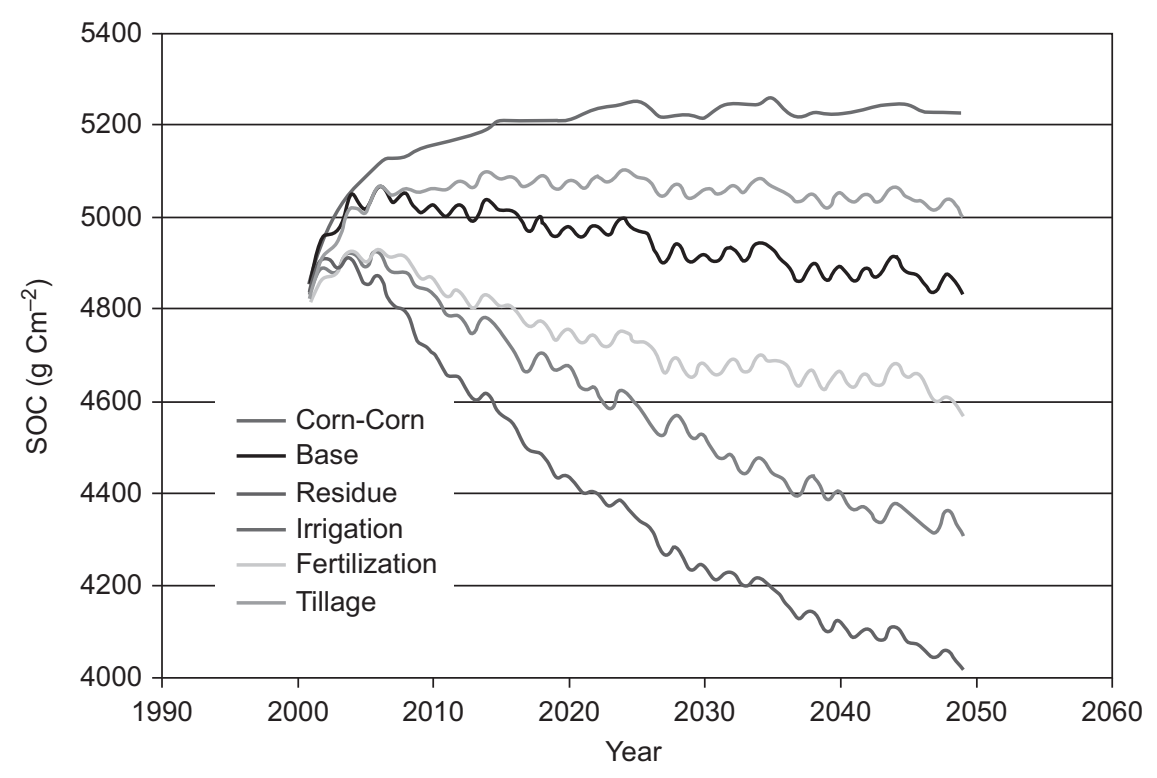

\section{FIGURE 18.3}

Soil carbon dynamics under various management practices. The scenarios are specified in Table 18.1. Please see color plate section at the back of the book.

fraction of residue removed from the site. High removal rates would accelerate and increase the reduction of SOC (Gollany et al., 2012).

Replacing corn-soybean rotation by continuous corn sequestered $371 \mathrm{~g} \mathrm{C} \mathrm{m}^{-2}$ (or $7.7 \%$ ) of SOC during the 50-year simulation. Implementing no-till instead of the conventional tillage would increase SOC by $148 \mathrm{~g} \mathrm{C} \mathrm{m}^{-2}$ (or $3.1 \%$ ). Irrigation and fertilization are important practices for maintaining high SOC content as well. Without irrigation and fertilization, SOC would decrease by 546 and $280 \mathrm{~g} \mathrm{C} \mathrm{m}^{-2}$, respectively. Of course, those changes should be interpreted with caution. First, the relative fast increases of SOC in the initial years might be due to artifacts of improper initialization of the SOC pools. We did not spin-up (i.e. start the model runs years earlier than the intended starting date of model simulations to make sure that the model runs had enough time to stabilize and the states of the models were close to reality at the starting date) the model runs because of the difficulties in prescribing the details of management practices before the installation of the flux tower at the sites. Second, the changes are very small if they are represented on the basis of total soil mass, and very difficult to detect in the field. For example, replacing the corn-soybean rotation with continuous corn resulted in a $7.7 \%$ increase in SOC, which is equivalent to the standard errors of the field measurements of SOC (about 5 to 8\%) (Verma et al., 2005). Therefore, given the challenges in measuring small SOC change in the field, these modeling results do not conflict with field observations of C neutrality at these sites (Verma et al., 2005).

\section{Quantification of Regional Carbon Stocks and GHG Fluxes}

\section{PRAIRIE POTHOLE REGION}

Figure 18.4 shows the simulated spatial details of SOC change in the study area of the Prairie Pothole Region. On average, this system lost SOC at a rate of $5 \mathrm{~g} \mathrm{C} \mathrm{m}^{-1} \mathrm{yr}^{-1}$ from 1998 to 2007. However, the spatial variability of SOC change was high varying from strong sources $\left(<-60 \mathrm{~g} \mathrm{C} \mathrm{m}^{-1} \mathrm{yr}^{-1}\right)$ to strong sinks $\left(>60 \mathrm{~g} \mathrm{C} \mathrm{m}^{-1} \mathrm{yr}^{-1}\right)$. Variability in SOC responses was mainly caused by the spatial variability of management practices (e.g. crop rotation) and the existing SOC storage. The $\mathrm{C}$ sources mainly occurred in cropping systems with high levels of baseline SOC, which tend to be $\mathrm{C}$ sources following the conversion of grassland to cropland (Bellamy et al., 2005; Liu et al., 2010; Tan et al., 2006a, b, 2007). Accordingly, land use change 


\section{SECTION 4}

Modeling to Estimating Soil Carbon Dynamics and Greenhouse Gas Flux

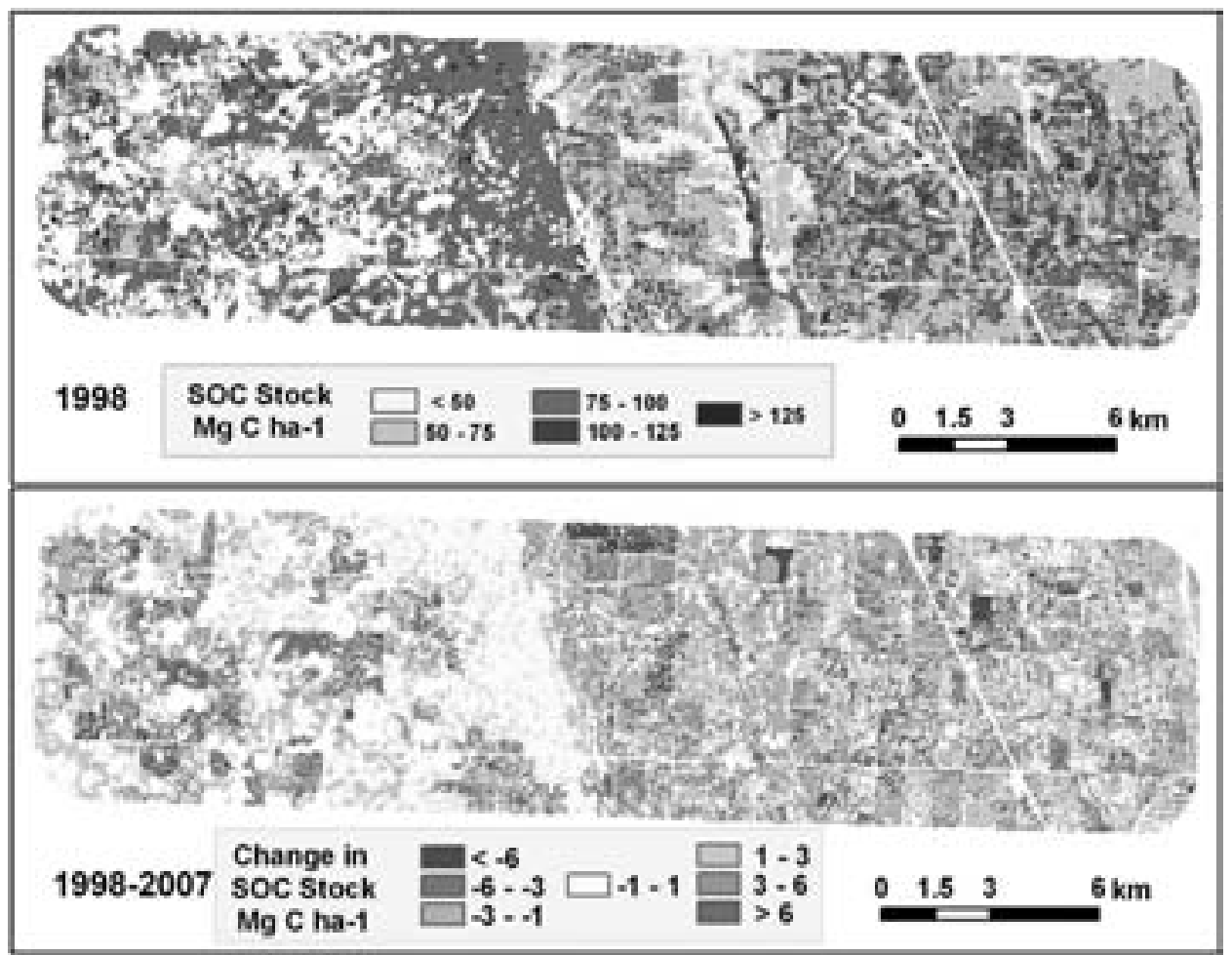

FIGURE 18.4

GEMS simulated changes in soil organic carbon in the $0-100 \mathrm{~cm}$ depth within the study area of the Prairie Pothole region. Please see color plate section at the back of the book.

was a major factor driving SOC dynamics. Planted areas for barley (Hordeum vulgare L.), spring wheat (Triticum aestivum L.), and sunflower (Helianthus annuus L.) declined sharply from 1998 to 2007 , while the areas of corn and soybean expanded from 0.5 to $13.5 \%$ and from 1.0 to $14.6 \%$, respectively. In fact, the SOC loss rate in the region has become smaller since the mid1980 s due mainly to an expansion of conservation tillage and restoration of grassland from croplands in the last decade (Follett et al., 2009).

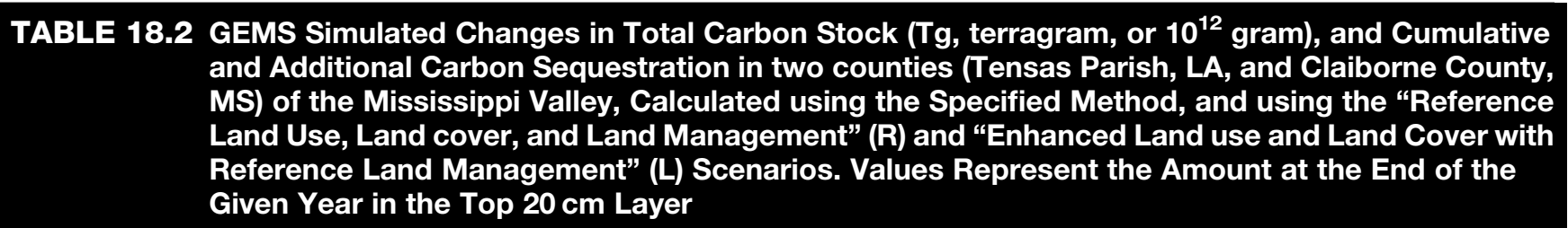

Total carbon Stocks, by method, Cumulative carbon sequestration, Additional carbon sequestration, in $\mathrm{Tg}^{1}$ by method, in $\mathrm{Tg}^{1}$ by method, in $\mathrm{Tg}^{2}$

\begin{tabular}{|c|c|c|c|c|c|c|c|c|c|}
\hline Year & $\begin{array}{c}\text { GEMS- } \\
\text { spreadsheet }\end{array}$ & $\begin{array}{l}\text { GEMS- } \\
\text { Century }\end{array}$ & $\begin{array}{l}\text { GEMS- } \\
\text { EDCM }\end{array}$ & $\begin{array}{c}\text { GEMS- } \\
\text { spreadsheet }\end{array}$ & $\begin{array}{l}\text { GEMS- } \\
\text { Century }\end{array}$ & $\begin{array}{c}\text { GEMS- } \\
\text { EDCM }\end{array}$ & $\begin{array}{c}\text { GEMS- } \\
\text { spreadsheet }\end{array}$ & $\begin{array}{l}\text { GEMS- } \\
\text { Century }\end{array}$ & $\begin{array}{l}\text { GEMS- } \\
\text { EDCM }\end{array}$ \\
\hline 2001 & 40.91 & 34.22 & 43.30 & & & & & & \\
\hline 2010 & 43.45 & 38.37 & 42.56 & 2.54 & 4.15 & -0.74 & 0.30 & 0.47 & 0.02 \\
\hline 2020 & 45.57 & 42.11 & 43.71 & 4.67 & 7.90 & 0.41 & 0.52 & 0.54 & 0.15 \\
\hline 2030 & 47.32 & 45.88 & 45.24 & 6.41 & 11.66 & 1.94 & 0.90 & 0.95 & 0.39 \\
\hline 2040 & 48.48 & 49.14 & 46.70 & 7.58 & 14.92 & 3.39 & 1.27 & 1.42 & 0.82 \\
\hline 2050 & 49.36 & 51.89 & 48.07 & 8.45 & 17.67 & 4.76 & 1.64 & 1.75 & 1.08 \\
\hline
\end{tabular}

${ }^{1}$ Values were evaluated using the "enhanced land use and land cover with reference land management" (L) scenario.

${ }^{2}$ Values represent the difference between the $L$ scenario and the "reference land use and land cover and land management" (R) scenario. 


\section{MISSISSIPPI VALLEY}

Table 18.2 shows the dynamics of total carbon stocks as simulated by GEMS using GEMSspreadsheet, GEMS-Century, and GEMS-EDCM methods in the two counties in Mississippi Valley. Note that the results presented for the Mississippi Valley included not only agricultural lands but also forests, wetlands, and other land cover.

The initial conditions of carbon stocks in vegetation and soils were not synchronized among these models. The purpose was to preserve the uncertainty and mimic the general observation that different initial conditions are used by different modelers. Although the GEMS-Century method began with a lower carbon stock value in 2001, it reached a higher carbon stock value in 2050 than the other two models (GEMS-spreadsheet and EDCM) because of a higher carbon-sequestration rate during the study period. From 2001 to 2050, the total carbon sequestration (the net change in carbon stocks) calculated using the GEMS-CENTURY method $(17.67 \mathrm{Tg})$ was much higher than that calculated using the GEMS-Spreadsheet $(8.45 \mathrm{Tg})$ and GEMS-EDCM methods $(4.77 \mathrm{Tg}$ ) (Table 18.2). The corresponding annual rates of carbon sequestration were $0.35,0.17$, and $0.1 \mathrm{Tg} \mathrm{C} \mathrm{yr}^{-1}$ from the GEMS-CENTURY, GEMS-Spreadsheet, and GEMS-EDCM methods, respectively.

The differences shown here might be attributed to differences in the input data sources, initial parameter values, and simulation algorithms of each model, especially between the GEMSCENTURY and GEMS-EDCM methods. For example, a higher rate of carbon sequestration from the GEMS-CENTURY method might have been caused by the lower initial biomass carbon values, faster biomass accumulation (compared to the GEMS-Spreadsheet method), and SOC accumulation. In contrast, the lower carbon-sequestration estimate from the GEMS-EDCM method can be attributed to lower biomass accumulation (compared to the GEMS-Spreadsheet method) and SOC loss. Further study to reconcile the differences among the modeling approaches within GEMS should be conducted.

All three methods estimated significantly higher ecosystem carbon stocks for the "enhanced land use and land cover with reference land management" (L) scenario, indicating additional carbon sequestration of 1.64, 1.75, and $1.08 \mathrm{Tg}$ from the GEMS-Spreadsheet, GEMS-

CENTURY, and GEMS-EDCM methods, respectively, relative to the "reference land use, land cover, and land management" (R) scenario. These amounts represented an additional 20\%, $10 \%$, and $23 \%$ increase, respectively, above the carbon-sequestration values calculated using the R scenario (Table 18.2). The result suggests that these models, rather consistently, are capable of quantifying additional carbon sequestration from enhanced changes in land use and land cover activities such as the Wetland Reserve Program (NRCS, 2011), although their initialization and performance on the absolute estimates of $\mathrm{C}$ stocks were quite different.

Table 18.3 lists major differences in $\mathrm{CH}_{4}$ and $\mathrm{N}_{2} \mathrm{O}$ emissions between the GEMS-spreadsheet and GEMS-EDCM methods (no results were generated from the GEMS-CENTURY method). Table 18.3 revealed the following: (1) the GEMS-spreadsheet method estimated an annual $\mathrm{CH}_{4}$-emission rate on wetlands more than double that of the GEMS-EDCM method; (2) estimates of $\mathrm{N}_{2} \mathrm{O}$ emissions demonstrated opposite temporal trends, although both methods produced similar $\mathrm{N}_{2} \mathrm{O}$-emission rates; and (3) the GEMS-spreadsheet method showed small increases in annual emission rates of $\mathrm{CH}_{4}$ and $\mathrm{N}_{2} \mathrm{O}$, whereas the GEMS-EDCM method showed decreasing trends. Field studies in this region suggested both $\mathrm{CH}_{4}$ and $\mathrm{N}_{2} \mathrm{O}$ emission rates were greatly affected by soil moisture, temperature, and substrate availability, and thus varied considerably depending on site conditions. For example, $\mathrm{CH}_{4}$ emissions from rice paddies ranged from 2 to $1642 \mathrm{~kg} \mathrm{C} \mathrm{ha}^{-1} \mathrm{yr}^{-1}$ (Lindau et al., 1990). The complexity of ecosystems and the management practices in the region makes estimation of $\mathrm{N}_{2} \mathrm{O}$ and $\mathrm{CH}_{4}$ fluxes challenging. Additional work is needed to address discrepancies among different modeling approaches. For $\mathrm{CH}_{4}$ and $\mathrm{N}_{2} \mathrm{O}$ emissions, we found that uncertainty of the $\mathrm{CH}_{4}$ and $\mathrm{N}_{2} \mathrm{O}$ emission factors using the GEMS-spreadsheet method was very high. Reducing the uncertainty relies heavily on certainty 
TABLE 18.3 Annual Emission Rates of Methane and Nitrous Oxide (Gg, gigagram, or $10^{9} \mathrm{gram}$ ) and their Total Differences (between 2001 and 2050), for the "Reference Land use, Land cover, and Land Management" $(\mathrm{R})$ and the "Enhanced Land Use and Land Cover with Reference Land Management" (L) Scenarios

\begin{tabular}{|c|c|c|c|c|c|c|c|c|}
\hline \multirow{3}{*}{ Year } & \multicolumn{4}{|c|}{$\mathrm{CH}_{4}$ from wetland (Gg C) } & \multicolumn{4}{|c|}{$\mathrm{N}_{2} \mathrm{O}$ from all land (Gg N) } \\
\hline & \multicolumn{2}{|c|}{ GEMS-spreadsheet } & \multicolumn{2}{|c|}{ GEMS-EDCM } & \multicolumn{2}{|c|}{ GEMS-spreadsheet } & \multicolumn{2}{|c|}{ GEMS-EDCM } \\
\hline & $\mathbf{L}$ & $\mathbf{R}$ & $\mathbf{L}$ & $\mathbf{R}$ & $\mathbf{L}$ & $\mathbf{R}$ & $\mathbf{L}$ & $\mathbf{R}$ \\
\hline 2001 & 28.47 & 28.42 & 15.50 & 15.47 & 2.74 & 2.74 & 2.77 & 2.76 \\
\hline 2010 & 28.88 & 28.53 & 13.32 & 13.20 & 2.78 & 2.77 & 1.98 & 1.99 \\
\hline 2020 & 29.26 & 28.36 & 12.66 & 12.45 & 2.82 & 2.76 & 1.91 & 1.92 \\
\hline 2030 & 29.80 & 28.24 & 13.57 & 13.27 & 2.87 & 2.77 & 1.86 & 1.89 \\
\hline 2040 & 30.43 & 28.10 & 13.04 & 12.65 & 2.92 & 2.77 & 1.74 & 1.77 \\
\hline 2050 & 31.01 & 27.94 & 12.92 & 12.42 & 2.96 & 2.76 & 1.73 & 1.77 \\
\hline Difference & 2.54 & -0.48 & -2.58 & -3.05 & 0.22 & 0.02 & -1.04 & -0.99 \\
\hline
\end{tabular}

of field observations of $\mathrm{CH}_{4}$ and $\mathrm{N}_{2} \mathrm{O}$ fluxes at the regional scale. At present, field observations demonstrate a high uncertainty in GHG fluxes in the Mississippi Valley (Zhu et al., 2010).

\section{DISCUSSION}

Many site-level biogeochemical models have been developed and tested extensively over the past three decades. With proper calibration and validation, they can be used to quantify the impacts of various management practices on SOC and GHG fluxes in agricultural systems at the field scale. We have demonstrated this capability for GEMS-EDCM at a site in Nebraska.

Although many site-scale models have been applied to regional and global studies, the appropriateness and efficacy of such model extrapolation are not well addressed and tested in the literature (Parton et al., 1994). For example, to our knowledge, few models have the capability of systematically simulating the impacts of agricultural management practices over large areas. GEMS incorporates information from different sources into the modeling processes. In addition, the use of the model ensemble in GEMS makes it ideal to address uncertainties in model structure, model parameters, and input data. Results from the Mississippi Valley indicated that the differences among the models within GEMS (specifically the biases and errors in the individual models) are significant in the estimation of carbon dynamics and GHG fluxes. On the development or technical side of GEMS, procedures should be put in place to address issues across models within GEMS such as consistent initialization and automated schemes for constraining model simulations with observations from various sources and different spatial and temporal scales. GEMS is the biogeochemical modeling system for the U.S. Geological Survey's assessment of national potentials for biological C sequestration and reduction of $\mathrm{CH}_{4}$ and $\mathrm{N}_{2} \mathrm{O}$ emissions (Zhu et al., 2010). Existing algorithms will be tested and improved and new algorithms will be added, if needed.

In addition to the challenges in model development, a major difficulty is obtaining information about the multitude of agricultural practices that affect SOC and GHG fluxes (see Eagle et al. (2010) for an exhaustive list of agricultural land management practices). First, to our knowledge, there is no common data repository for sharing agricultural management practice data, and each project locates available data from various sources, collects, compiles, and uses it to prepare agricultural practice inputs. For example, the Forest and Agricultural Sector Optimization Model-Green House Gas version (FASOM-GHG) (Adams et al., 2005) has accomplished national data compilations for various cropland mitigation strategies including changing crop composition, rice acreage reduction, crop fertilizer rate reduction, crop tillage alteration, 
grassland conversion, and irrigated/dryland conversion for 63 U.S. production regions. Second, subtle but important relationships among practice data are not captured. For example, USDA Natural Resources Conservation Service (NRCS, 2002) observed that the Conservation Technology Information Center (CTIC) reported the area in various tillage systems by individual crops on an annual basis; however, it did not differentiate between long-term no-till practices versus intermittent or "rotational no till" (e.g. tilled corn-no-tilled soybean rotations). Third, there are uncertainties inherent in survey-based data such as sampling design. Fourth, some agricultural practices are not routinely monitored. For example, information about cover crop practices is scattered. Finally, these problems are exacerbated across local, regional and global scales of analysis. For example, the downscaling of agricultural practice projections from the Integrated Model to Assess the Global Environment (IMAGE, 2006) is limited to crop composition and fertilizer and manure use. These data challenges are opportunities to improve the analysis of potential SOC and GHG fluxes in agricultural systems.

\section{Acknowledgments}

The research was funded by the LandCarbon Project, Geographic Analysis and Monitoring (GAM) Program, and the Global Change Research and Development Program (R\&D) of the U.S. Geological Survey. Work of Zhengxi Tan, Mingshi Chen, Zhengpeng Li, and Shengli Huang (ARTS) was performed under USGS contract G08PC91508, and work of Jinxun Liu and Jennifer Oeding (SGT) and Claudia Young (ERT) was performed under USGS contract G10PC00044. Any use of trade, firm, or product names is for descriptive purposes only and does not imply endorsement by the U.S. government.

\section{References}

Adams, D., Alig, R., McCarl, B.A., Murray, B.C., 2005. FASOMGHG conceptual structure, and specification: documentation. Texas A\&M Univ., College Station, TX. Available at http://agecon2.tamu.edu/people/faculty/mccarlbruce/papers/1212FASOMGHG_doc.pdf (verified March 16, 2011).

Baker, J.M., Ochsner, T.E., Venterea, R.T., Griffis, T.J., 2007. Tillage and soil carbon sequestration: what do we really know? Agric. Ecosyst. Environ. 118, 1-5.

Bellamy, P.H., Loveland, P.J., Bradley, R.I., Lark, R.M., Kirk, G.J.D., 2005. Carbon losses from all soils across England and Wales 1978-2003. Nature 437, 245-248.

Bouwman, A.F., 1989. Modelling soil organic matter decomposition and rainfall erosion in two tropical soils after forest clearing for permanent agriculture. Land Degrad. Dev. 1, 125-140.

Cao, M., Marshall, S., Gregson, K., 1996. Global carbon exchange and methane emissions from natural wetlands: application of a process-based model. J. Geophys. Res. Atmos 101, 14399-14414.

Carroll, R., Pohll, G., Tracy, J., Winter, T., Smith, R., 2005. Simulation of a semipermanent wetland basin in the Cottonwood Lake area, east-central North Dakota. J. Hydrol. Eng. 10, 70-84.

Chen, M., Liu, S., Tieszen, L.L., Hollinger, D.Y., 2008. An improved state-parameter analysis of ecosystem models using data assimilation. Ecol. Modell. 219, 317-326.

Del Grosso, S.J., Parton, W.J., Adler, P.R., Davis, S.C., Keough, C., Marx, E., 2012. DayCent model simulations for estimating soil carbon dynamics and greenhouse gas fluxes from agricultural production systems (this volume). In: Liebig, M.A., Franzluebbers, A.J., Follett, R.F. (Eds.), Managing Agricultural Greenhouse Gases: Coordinated Agricultural Research through GRACEnet to Address our Changing Climate. Elsevier Publ., San Diego, CA.

Eagle, A.J., Henry, L.R., Olander, L.P., Haugen-Kozyra, K., Millar, N., Robertson, G.P., 2010. Greenhouse gas mitigation potential of agricultural land management in the United States: a synthesis of the literature. Technical Working Group on Agricultural Greenhouse Gases (T-AGG) Report; Companion Report to Assessing Greenhouse Gas Mitigation Opportunities and Implementation Options for Agricultural Land Management in the United States, NI R 10-04. Nicholas Inst. for Environ. Policy Solutions, Duke Univ., Durham, NC. Available at http://nicholasinstitute.duke.edu/ecosystem/land/TAGGDLitRev (verified February 23, 2010).

EPA-Western Ecology Division, 2010. US Level III Descriptions, Level III and IV Ecoregions of the Continental United States. EPA, Corvallis, OR. Available at http://www.epa.gov/wed/pages/ecoregions/level_iii_iv.htm\#Level \%20III (verified March 14, 2011).

Faulkner, S., Barrow, W., Keeland, B., Walls, S., Telesco, D., 2011. Effects of conservation practices on wetland ecosystem services in the Mississippi Alluvial Valley. Ecol. Appl. 21 (Suppl. 3), S31-S48.

Follett, R.F., Kimble, J.M., Pruessner, E.G., Samson-Liebig, S., Waltman, S., 2009. Soil organic carbon stocks with depth and land use at various U.S. sites. In: Lal, R., Follett, R.F. (Eds.), Soil Carbon Sequestration and the Greenhouse Effect, second ed.). SSSA Spec. Publ. 57. ASA-CSSA-SSSA, Madison, WI, pp. 29-46. 
Gollany, H.T., Follett, R.F., Liang, Y., 2012. CQESTR simulations of soil organic carbon dynamics (this volume). In: Liebig, M.A., Franzluebbers, A.J., Follett, R.F. (Eds.), Managing Agricultural Greenhouse Gases: Coordinated Agricultural Research through GRACEnet to Address our Changing Climate. Elsevier Publ., San Diego, CA.

Harden, J.W., Sharpe, J.M., Parton, W.J., Ojima, D.S., Fries, T.L., Huntington, T.G., Dabney, S.M., 1999. Dynamic replacement and loss of soil carbon on eroding cropland. Global Biogeochem. Cycles 13, 885-901.

Hay, R.K.M., 1995. Harvest index: a review of its use in plant breeding and crop physiology. Ann. Appl. Biol. 126, $197-216$.

IMAGE, 2006. Integrated modelling of global environmental change. An overview of IMAGE 2.4. ( ) Netherlands Environ. Assess. Agency (MNP), Bilthoven Oct. 2006, MNP publication number 500110002/2006.

IPCC, 2003. Good practice guidance for land use, land-use change and forestry. Inst. for Global Environ. Strategies for the IPCC, Hayama, Kanagawa, Japan.

Kanwar, R.S., Baker, J.L., Baker, D.G., 1988. Tillage and split N-fertilization effects on subsurface drainage water quality and crop yields. Trans. Am. Soc. Agric. Eng. 31, 453-461.

Li, C.S., 2000. Modeling trace gas emissions from agricultural ecosystems. Nutr. Cycling Agroecosyst. 58, 259-273.

Lindau, C.W., Patrick, W.H., Delaune, R.D., Reddy, K.R., 1990. Rate of accumulation and emission of N2, N2O and CH4 from a flooded rice soil. Plant and Soil 129, 269-276.

Liu, J., Liu, S., Loveland, T.R., Tieszen, L.L., 2008. Integrating remotely sensed land cover observations and a biogeochemical model for estimating forest ecosystem carbon dynamics. Ecol. Modell 219, 361-372.

Liu, S., 2009. Quantifying the spatial details of carbon sequestration potential and performance. Geophys. Monogr. $183,117-128$.

Liu, S., Bliss, N., Sundquist, E., Huntington, T.G., 2003. Modeling carbon dynamics in vegetation and soil under the impact of soil erosion and deposition. Global Biogeochem. Cycles 17, 1074.

Liu, S., Kaire, M., Wood, E., Diallo, O., Tieszen, L.L., 2004a. Impacts of land use and cimate change on carbon dynamics in south-central Senegal. J. Arid Environ 59, 583-604.

Liu, S., Liu, J., Loveland, T.R., 2004b. Spatial-temporal carbon sequestration under land use and land cover change. In: Bridging the Pacific and Atlantic, Proc., Geospatial Information Research, Int. Conf. on Geoinformatics, 12th, Univ. of Gävle, Sweden. 7-9 June 2004. Gävle Univ. Press, pp. 525-532.

Liu, S., Loveland, T.R., Kurtz, R.M., 2004c. Contemporary carbon dynamics in terrestrial ecosystems in the southeastern plains of the United States. Environ. Manage. 33, S442-S456.

Liu, S., Reiners, W.A., Keller, M., Schimel, D.S., 1999. Model simulation of changes in $\mathrm{N}_{2} \mathrm{O}$ and $\mathrm{NO}$ emissions with conversion of tropical rain forests to pastures in the Costa Rican Atlantic Zone. Global Biogeochem. Cycles 13, 663-677.

Liu, S., Tan, Z., Li, Z., Zhao, S., Yuan, W., 2010. Are soils of Iowa USA currently a carbon sink or source? Simulated changes in SOC stock from 1972 to 2007. Agric. Ecosyst. Environ. 140, 106-112.

Mac, M.J., Opler, P.A., Puckett Haeker, C.E., Doran, D.P., 1998. Status and trends of the nation's biological resources. Vol. 1-2. U.S. Geol. Survey, Reston, VA.

McCarty, G.W., Ritchie, J.C., 2002. Impact of soil movement on carbon sequestration in agricultural ecosystems. Environ. Pollut. 116, 423-430.

Metherell, A.K., Harding, L.A., Cole, C.V., Parton, W.J., 1993. CENTURY soil organic matter model environment: technical documentation, Agroecosystem Version 4.0. USDA, Agric. Res. Serv., Great Plains System Res. Unit, Fort Collins, CO.

NRCS, 2011. Wetlands Reserve Program. USDA, Washington, DC. Available at http://www.nrcs.usda.gov/programs/ wrp (verified June 22, 2011).

NRCS, 2002. Quantifying the change in greenhouse gas emissions due to natural resource conservation practice application in NE, "The Nebraska Carbon Storage Project" USDA, Report to the Nebraska Conservation Partnership, March 2002. http://dnr.ne.gov/Carbon/NebraskaNRCS.pdf (accessed April 21, 2011).

Parton, W.J., Ojima, D.S., Schimel, D.S., 1994. Environmental change in grasslands: assessment using models. Clim. Change 28, 111-141.

Parton, W.J., Schimel, D.S., Cole, C.V., Ojima, D.S., 1987. Analysis of factors controlling soil organic-matter levels in Great Plains grasslands. Soil Sci. Soc. Am. J. 51, 1173-1179.

Parton, W.J., Scurlock, J.M.O., Ojima, D.S., Gilmanov, T.G., Scholes, R.J., Schimel, D.S., Kirchner, T., Menaut, J.C., Seastedt, T., Garcia Moya, E., Kamnalrut, A., Kinyamario, J.I., 1993. Observations and modeling of biomass and soil organic matter dynamics for the grassland biome worldwide. Global Biogeochem. Cycles 7, 785-809.

Paustian, K., Schuler, J., Killian, K., Chambers, A., Del Grosso, S., Easter, M., Alvaro-Fuentes, J., Gurung, R., Johnson, G., Merwin, M., Ogle, S., Olson, C., Swan A,, Williams, S., Vining, R. COMET2.0 - Decision Support System for Agricultural Greenhouse Gas Accounting. In M.A. Liebig, A.J. Franzluebbers, and R.F. Follet (ed.) Managing Agricultural Greenhouse Gases. Academic Press - Elsevier, Amsterdam. In Press. 
Renault, P., Sierra, J., 1994. Modeling oxygen diffusion in aggregated soils: II. Anaerobiosis in topsoil layers. Soil Sci. Soc. Am. J. 58, 1023-1030.

Renault, P., Stengel, P., 1994. Modeling oxygen diffusion in aggregated soils: I. Anaerobiosis inside the aggregates. Soil Sci. Soc. Am. J. 58, 1017-1023.

Sohl, T.L., Sayler, K.L., Drummond, M.A., Loveland, T.R., 2007. The FORE-SCE model: a practical approach for projecting land cover change using scenario-based modeling. J. Land Use Sci. 2, 103-126.

Stallard, R.F., 1998. Terrestrial sedimentation and the carbon cycle: coupling weathering and erosion to carbon burial. Global Biogeochem. Cycles 12, 231-257.

Tan, Z., Johnston, C.A., Liu, S., Loveland, T.R., Tieszen, L.L., Kurtz, R., Liu, J., 2005. Soil organic carbon dynamics as related to land use history in the northwestern Great Plains. Global Biogeochem. Cycles 19 GB3011.

Tan, Z., Lal, R., Liu, S., 2006a. Using experimental and geospatial data to estimate regional carbon sequestration potential under no-till management. Soil Sci. 171, 950-959.

Tan, Z., Lal, R., Smeck, N.E., Calhoun, F.G., 2004. Relationships between surface soil organic carbon pool and site variables. Geoderma 121, 187-195.

Tan, Z., Liu, S., Johnston, C.A., Liu, J., Tieszen, L.L., 2006b. Analysis of ecosystem controls on soil carbon sourcesink relationships in the northwest Great Plains. Global Biogeochem. Cycles 20 GB4012.

Tan, Z., Liu, S., Li, Z., Loveland, T.R., 2007. Simulated responses of soil organic carbon stock to tillage management scenarios in the northwest Great Plains. Carbon Balance Manage 2, 7.

Tan, Z., Liu, S., Tieszen, L.L., Tachie-Obeng, E., 2009a. Simulated dynamics of carbon stocks driven by changes in land use, management and climate in a tropical moist ecosystem of Ghana. Agric. Ecosyst. Environ. 130, 171-176.

Tan, Z., Tieszen, L.L., Liu, S., Tachie-Obeng, E., 2010. Modeling to evaluate the response of savanna-derived cropland to warming-drying stress and nitrogen fertilizers. Clim. Change 100, 703-715.

Tan, Z., Tieszen, L.L., Tachie-Obeng, E., Liu, S., Dieye, A.M., 2009b. Historical and smulated ecosystem carbon dynamics in Ghana: land use, management, and climate. Biogeosciences 6, 45-58.

USDA-Forest Service, 2010. Forest inventory and analysis national program. USDA, Arlington, VA. Available at http://www.fia.fs.fed.us/tools-data (verified January 25, 2011).

USDA-National Agricultural Statistics Service, 2010. The census of agriculture. USDA, Washington, DC. Available at http://www.agcensus.usda.gov/ (verified December 18, 2010).

USDA-National Agricultural Statistics Service, 2011. Cropland data layer-examples. USDA, Washington, DC. Available at http://www.nass.usda.gov/research/Cropland/sarsexample3.html (verified February 10, 2011).

USDA-NRCS, 2006. Soil survey of Tensas Parish, Louisiana, Louisiana Online Soil Survey Manuscripts. USDA, Washington, DC. Available at http://soils.usda.gov/survey/online_surveys/louisiana/index.html (verified March $16,2011)$.

USDA-SCS, 1963. Soil survey, Claiborne County, Mississippi, Mississippi Online Soil Survey Manuscripts. USDA, Washington, DC. Available at http://soils.usda.gov/survey/online_surveys/mississippi/index.html (verified March 16, 2011).

Van Dam, D., Veldkamp, E., Van Breemen, N., 1997. Soil organic carbon dynamics: variability with depth in forested and deforested soils under pasture in Costa Rica. Biogeochemistry 39, 343-375.

Van Oost, K., Quine, T.A., Govers, G., De Gryze, S., Six, J., Harden, J.W., Ritchie, J.C., McCarty, G.W., Heckrath, G., Kosmas, C., Giraldez, J.V., da Silva, J.R.M., Merckx, R., 2007. The impact of agricultural soil erosion on the global carbon cycle. Science 318, 626-629.

Verma, S.B., Dobermann, A., Cassman, K.G., Walters, D.T., Knops, J.M., Arkebauer, T.J., Suyker, A.E., Burba, G.G., Amos, B., Yang, H., 2005. Annual carbon dioxide exchange in irrigated and rainfed maize-based agroecosystems. Agric. For. Meteorol. 131, 77-96.

Voroney, R.P., Van Veen, J.A., Paul, E.A., 1981. Organic C dynamics in grassland soils. 2. Model validation and simulation of the long-term effects of cultivation and rainfall erosion. Can. J. Soil Sci. 61, 211-224.

Zhang, Y., Li, C., Zhou, X., Moore III, B., 2002. A simulation model linking crop growth and soil biogeochemistry for sustainable agriculture. Ecol. Modell. 151, 75-108.

Zhao, S., Liu, S., Li, Z., Sohl, T.L., 2009. Ignoring detailed fast-changing dynamics of land use overestimates regional terrestrial carbon sequestration. Biogeosciences 6, 1647-1654.

Zhao, S., Liu, S., Li, Z., Sohl, T.L., 2010. Federal land management, carbon sequestration, and climate change in the southeastern US: a case study with Fort Benning. Environ. Sci. Technol. 44, 992-997.

Zhu, Z., Bergamaschi, B., Bernknopf, R., Clow, D., Dye, D., Faulkner, S., Forney, W., Gleason, R., Hawbaker, T., Liu, J., Liu, S., Prisley, S., Reed, B., Reeves, M., Rollins, M.G., Sleeter, B., Sohl, T.L., Stackpoole, S., Stehman, S., Striegl, R., Wein, A., 2010. A method for assessing carbon stocks, carbon sequestration, and greenhouse-gas fluxes in ecosystems of the United States under present conditions and future scenarios. U.S. Geol. Survey Sci. Investigations Rep. 2010-5233. Reston, VA. 
